\title{
Teachers' Key Competencies for Innovative Teaching
}

\author{
Nikola Simonović \\ 1University in Niš, Faculty of Philosophy, Serbia, e-mail: nikola.simonovic84@hotmail.com
}

\begin{abstract}
The educational process is by its nature and essence very dialectical, so it necessarily requires teachers to have a developed whole set of various competencies. The aim of the research was to examine teachers on self-assessment of competencies that were crucial for innovating the teaching process. The sample of respondents included 1300 elementary and secondary school teachers in the territory of Southern Serbia. The instrument used was a five-point TCS scale of attitudes, with a total of 48 items (individual competencies). The results of the analysis showed that teachers, based on their self-assessments, highly value all diverse groups of competencies, which fully confirms the general hypothesis. The results also showed the existence of statistically significant differences in the degree of expression of attitudes about competency groups with regard to independent research variables, within special hypotheses, based on which the first was rejected, the second partially and the third and fourth special hypothesis fully confirmed. The issue of key competencies of teachers is certainly one of the fundamental issues when it comes to quality teaching, its innovation, generally successful and efficient dealing with the educational process. Based on these postulates, there is hope that the obtained research results will represent a good starting point and incentive for further research work in this field in the future.
\end{abstract}

Keywords: teacher, competencies, innovations in teaching, reflective practice.

\section{Introduction}

A completely defined expertise and professionalism are recognized through certain special abilities, ie. the competence of teachers to plan and organize certain activities, achieve or realize the intended goals and evaluate the teaching process at all stages. A well-coordinated education system encourages the nurturing of a diverse group of competencies and directs teachers towards continuous personal and professional improvement and development, as well as permanent learning.

The term competencies is defined and interpreted differently depending on the specifics of the purpose, approach and context in which it is used as a term, but in many definitions common features can be found Andevski and Arsenijević (2012). The term competencies stands for a complex mosaic of characteristics, knowledge, beliefs, abilities, skills, experiences, motivation, value attitudes, habits and self-regulation as interdependent and connected elements that enable an individual to be active and efficient in a certain specific situation.

Competences are a dynamic and multidimensional category subject to constant change, enrichment and upgrading, which is influenced by various factors that are cause-and-effect related. Competencies are the core of every professional success and achievement, no matter what one does for life. Defined as such, key competencies are crucial for the work and actions of all individuals in society, including teachers, and are based on goals that are embedded in all school subjects.

The necessity of having a wide group of teacher competencies is pointed out by various authors (Tapani and Salonen, 2019; Teodorović, Milin and Stanković, 2019; Call, 2018; Turk, 2016; Jorgić, 2015; Bertschy, Künzli and Lehmann, 2013; Gojkov, 2012; Nessipbayeva, 2012; Panić and Wubbels, 2010; Selvi, 2010). In the further review, various groups of teacher competencies were analyzed.

Interpersonal competencies specifically include possessing the necessary human qualities, knowledge, abilities and skills related to processes and interpersonal relationships in teaching, possessing the ability to create trust and empathy towards colleagues and other individuals, creating positive interdependence and equal participation in work, ability to act by personal example with expressed propensity for individual and group responsibility (Englefield et al., 2019; Brundiers and Wiek, 2017; Gojkov, 2012). Certain authors (Jurčić, 2014; Vrkić-Dimić, 2013; Andevski and Arsenijević, 2012), see "Corresponding author: nikola.simonovic84@hotmail.com 
them in the form of personal competencies that include teacher personality traits, personal potentials, personal and interpersonal skills.

Socioemotional group of competencies related to the ability to provide additional support to students from vulnerable social groups to realize educational potential in complete socioemotional development, but also the ability to actively contribute to an inclusive approach to education, encouraging students to respect universal human and national values, respect for diversity and multiculturalism, is particularly highlighted by (Fiorilli et al., 2017; Brust Nemet and Velki, 2016; Dorman, 2015; Gojkov and Stojanović, 2015; Jurčić, 2014; Vrkić-Dimić, 2013; Andevski and Arsenijević, 2012; Livazović, 2012).

In the light of emphasizing the importance and necessity of possessing competence, pedagogicalpsychological is emphasized by (Tapani and Salonen, 2019; Dubovicki and Jukić, 2017; Jorgić, 2015; Buljubašić-Kuzmanović, 2014; Jurčić, 2014; Đuranović, Klasnić and Lapat, 2013; Voss and Kunter, 2013; Liakopoulou, 2011). This group of competencies includes, among other things, knowledge of general principles, goals, outcomes of education and upbringing, general and special standards of student achievement, knowledge of psychological bases of working with children, possession of ability to apply different types of motivation, specific knowledge of different learning styles and strategies of learning, as well as taking measures to support students with learning difficulties.

Subject-professional group of competencies related to knowledge of the entire education system, standards, strategies, legislation, possession of self-assessment and personal orientation in the field of planning their own professional development, but also knowledge and extremely good management of the scientific discipline to which the subject belongs is particularly highlighted by (Call, 2018; Nikitchenko, 2017; Sigrid-Blömeke, 2017; Jurčić, 2014; Baumert and Kunter, 2013; Guseva, 2013; Kunter et al., 2013; Andevski and Arsenijević, 2012; Anugerahwati and Saukah, 2010).

The importance of didactic competencies is emphasized by (Tejedor et al., 2019; Milošević and Medić, 2018; Dubovicki and Jukić, 2017; Gojkov and Stojanović, 2015; Malaspina, Mallart and Font, 2015; Jurčić, 2014; Kuhnigk, Schreiner and Harendza, 2013; Tichá and Hošpesová, 2013; Vrkić-Dimić, 2013; Gojkov, 2012). The didactic group of competencies implies the possession of the ability of didactic content design with the application of various didactic methods, techniques, forms of work, available teaching resources and aids for the efficiency and effectiveness of the teaching process, as well as the development of new and creative didactic materials for teaching.

The issue of methodological education of teachers for reflective practice is one of the crucial issues when it comes to effective teaching and quality education. The necessity of having methodological education, but also methodological culture and teacher competence, which includes knowledge of scientific research methodology, methodological scientific terminology, ways of valid statistical processing, structure of writing a scientific report, mastering intellectual work techniques that are universal for all sciences, but also possessing examination skills, studies and research of pedagogical reality and own practice, as well as the ability to participate in research conducted by other researchers, is pointed out by numerous authors (Albareda-Tiana et al., 2018; Koichu and Pinto, 2018; Taylor, 2017; Letina, 2016; Wareerat et al., 2016). We will indicate that it is closely related to methodological competencies as a related group of competencies in relation to scientific research.

The modern era of the rule of information and communication technologies, among other things, requires a change in the professional development of teachers, which must primarily be based on professional competencies in certain domain because it is indisputable that today, "ICT provides excellent and very useful changes in teaching and learning" (Stošić, Dermendzhieva and Tomczyk, 2020, p. 132133). In this context, numerous authors emphasize information and communication competencies (RicardoBarreto et al., 2020; Chen, Gorbunova and Masalimova, 2017; Feng et al., 2017; Turk, 2016; Wambiri and Ndani, 2016; Adelabu and Adu, 2015; Chai, Koh and Tsai, 2013; Branekova, 2010; Cortes and Lau, 2009), which are an integral and inseparable component of multimedia (Instefjord and Munthe, 2017; Matijevic and Topolovčan, 2017; Turk, 2016; Duh, Bratina and Krašna, 2013; Witfelt, 2000), according to other authors. Accordingly, it is important to note that media literacy and media competence are "important features in the process of self-realization of an individual in modern media society", as the authors state (Maksimović, Osmanović and Mamutović, 2020, str. 2688), and to represent "basic skills of the $21^{\text {st }}$ century" (Novković Cvetković, Stošić and Belousova, 2018, p. 1108). If we take into account the fact that multimedia, with its existence and constant progress, poses new challenges to the entire educational technology, as well as the teaching process itself, and that they "become an unavoidable segment in the process of acquiring knowledge" (Stanković, Maksimović and Osmanović, 2018, p. 107), it is quite clear and justified to pay significant attention to multimedia competencies. Some authors especially emphasize the development of digital competencies of teachers (Cabero-Almenara et al., 2020; Falloon, 2020; Miljković and Trnavac, 2020; Mirete et al., 2020; Müller and Varga, 2020; Ristić, 2018; Ferrari, 2012), because digital literacy is 
necessary for functioning in a system of digital education that is constantly changing and transforming. Numerous advantages of having this competence are that, among other things, "a digitally competent and literate teacher can communicate with colleagues, students and parents, using various digital tools and applications" (Kožuh, Maksimović and Osmanović Zajić, 2021, p. 161).

We emphasize the leadership roles of teachers with prominent organizational and "managerial"skills in school from the aspect of participation in decision-making and responsibility, through the phrase "leadership in education". In this light, we can speak of organizational competencies that are in particular highlighted by (Chiriac and Granström, 2012; Fairman and Mackenzie, 2012; Xu and Patmor, 2012). Building on the previous, Turk (2016), emphasizes the importance of organizational competence in human resources management as the main feature of every manager in leading people and employees, while the authors (Tapani and Salonen, 2019), emphasize the importance of competence for pedagogical leadership that is, leadership that encompasses school management. This group of competencies includes, among other things, the ability to motivate associates to participate and openly share and use available useful knowledge to make important decisions, the ability to shape a cooperative atmosphere and collaborative climate, facilitate the dissemination of knowledge through organizational culture and initiative, as well as emphasized traits of leaders and inclinations towards leadership, ie. leadership without compromising group cohesion and team spirit.

Self-initiative in professional development, intrinsic motivation for reflective and critical reflection on practice, but also openness to innovation and change (Stanković and Stanojević, 2019; Nikolić, 2015; Schellenbach-Zell and Gräsel, 2010), represent significant features of professionalism. Based on competencies, their development, expansion and complexity, professionalism is one of the essential factors guaranteeing quality and success at work, in the teaching and the entire educational process.

\section{Materials and Methods}

Today's school, in accordance with modern tendencies, indisputably needs a "new profile" of a modern teacher, with a wide range of developed competencies, which would enable them to successfully organize work, motivate and encourage students, critically reflect on their practice, independently research and use these results for the purpose of self-improvement. In accordance with the above and the overall issue, which is very topical, the question necessarily arises: Do teachers have a wide group of diverse, as well as individual competencies, within these groups, which are key to innovating their own, but also the entire educational and teaching practice?

The subject of this research, therefore, is the self-assessment of elementary and secondary school teachers in the territory of Southern Serbia on the competence to introduce innovations in teaching and reflective practice, expressed through the evaluation of a wide and diverse group of competencies and individual competencies necessary for successful and efficient educational work.

The general hypothesis of the research is: It is assumed that elementary and secondary school teachers in the territory of Southern Serbia, based on their self-assessments, should highly value all groups, including individual competencies within these diverse groups, which in the literature are considered key to innovation of the teaching process, but also very important in pedagogical activities in general.

Special research hypotheses, 4 of them, refer to assumptions about: existence or non-existence of statistically significant differences in teachers' attitudes about competence groups - interpersonal, socioemotional, pedagogical-psychological, subject-professional, didactic, methodological-researchstatistical, multimedia-digital and organizational, in relation to each of the independent research variables separately.

The sample of respondents is appropriate and included 1300 elementary and secondary school teachers surveyed on the territory of Southern Serbia. The survey was conducted during October, November and December 2019, as well as January, February and early March in 2020 in 16 elementary schools, 3 highschools and 11 secondary vocational schools. 
Table 1.

Sample structure according to independent variables included in the research

\begin{tabular}{|c|c|c|c|}
\hline \multicolumn{2}{|c|}{ Sample structure according to independent variables included in the research } & $f$ & $\%$ \\
\hline \multirow{2}{*}{ Type of school } & Elementary & 588 & $45.2 \%$ \\
\hline & Secondary & 712 & $54.8 \%$ \\
\hline \multirow{4}{*}{ Academic achievement } & 6-7 & 136 & $10.5 \%$ \\
\hline & $7.01-8$ & 385 & $29.6 \%$ \\
\hline & $8.01-9$ & 549 & $42.2 \%$ \\
\hline & $9.01-10$ & 230 & $17.7 \%$ \\
\hline \multirow{2}{*}{$\begin{array}{l}\text { Attending seminars in the field of educational technologies and } \\
\text { applications of multimedia systems in teaching }\end{array}$} & Yes & 898 & $69.1 \%$ \\
\hline & No & 402 & $30.9 \%$ \\
\hline \multirow{2}{*}{ Application of internal evaluation in teaching } & Yes & 740 & $56.9 \%$ \\
\hline & No & 560 & $43.1 \%$ \\
\hline
\end{tabular}

The method used in this research is a descriptive-scientific-research method. In accordance with the nature of the issue and the choice of an adequate method as a data collection technique, the scaling technique was applied. The instrument used in this research for self-assessment of teachers' attitudes about competencies was a five-point scale of attitudes, TCS scale (Teacher Competence Scale), which contained eight sub-scales, and within each six statements (individual items), therefore a total of 48 items. The assessment scale was constructed independently for the purposes of this research, and was anonymous. The scale started from the possibility of low, ie. non-evaluation (No, not at all - 1), through partial (To a lesser extent - 2), (I am undecided - 3), (To a greater extent - 4), to high evaluation (It is extremely important - 5).

The reliability of the instrument (Teacher Competence Scale - TCS and its subscales) was examined by Cronbach's Alpha coefficient of internal consistency.

Table 2.

The reliability of Teacher Competence Scale - TCS

\begin{tabular}{ccccc}
\hline Scale & AS & SD & a & $\begin{array}{c}\text { Number of } \\
\text { items }\end{array}$ \\
\hline Teacher Competence Scale & 205.84 & 17.366 & 0.928 & 48 \\
\hline
\end{tabular}

Table 2 shows that the Teacher Competence Scale - TCS has a high and acceptable reliability (Cronbach $a=0.928)$. The data obtained by this procedure indicate that the instrument independently constructed for the purposes of this research has good psychometric characteristics and is suitable for measuring attitudes about teacher competencies.

Table 3.

Reliability of subscales of teacher competences

\begin{tabular}{ccccc}
\hline Subscales of competences & AS & SD & a & $\begin{array}{c}\text { Number of } \\
\text { items }\end{array}$ \\
\hline Intrerpersonal & 4.492 & 2.463 & 0.735 & 6 \\
Socioemotional & 4.253 & 2.867 & 0.693 & 6 \\
Pedagogical-psychological & 4.376 & 2.841 & 0.722 & 6 \\
Subject-professional & 4.299 & 2.865 & 0.707 & 6 \\
Didactic & 4.241 & 2.912 & 0.704 & 6 \\
Methodological-statistical-research & 4.086 & 3.683 & 0.816 & 6 \\
Multimedia-digital & 4.219 & 3.701 & 0.832 & 6 \\
Organizatonal & 4.336 & 2.846 & 0.736 & 6 \\
\hline
\end{tabular}

In Table 3, we notice that seven of the eight sub-scales of teacher competencies have an acceptable reliability (above Cronbach's $a=0.7$ ), except for the scale of socioemotional competencies whose reliability is (Cronbach's $\alpha=0.693$ ), below the limit of the acceptable reliability. The reliability of individual subscales, which are, therefore, at a satisfactory level, given that it is an assessment scale, testifies to the existence of a certain internal coexistence of the instrument itself.

Among the statistical procedures, in addition to descriptive statistics (frequencies, percentages, minimum and maximum values of the empirical range), AS arithmetic mean, SD standard deviation, 
Crombach alpha was used within the statistics to check the reliability of instruments and examine the internal correlation of sub-scales.

To determine statistically significant differences in attitudes about competency groups as dependent variables in relation to the offered independent variables, One-factor analysis of variance - ANOVA(F-test) and t-test were used.

\section{Results}

The statistical analysis aimed to provide data and results based on which the general, but also specific research hypotheses would be confirmed or refuted. In order to verify them, from the statistical procedures, the Analysis of variance and the Post hoc test were applied to the independent variable - academic success. In all others, a parametric t-test was used to determine statistically significant differences in attitudes about competency groups. By applying descriptive statistical analysis, for the mentioned groups of competencies, the basic descriptive measures of the examined research variables were determined.

\section{Table 4.}

Basic parameters of teachers' attitudes about competencies

\begin{tabular}{lccccccc}
\hline \multicolumn{1}{c}{ Subscales of competencies } & $\begin{array}{c}\text { Theor. } \\
\text { min. }\end{array}$ & $\begin{array}{c}\text { Theor. } \\
\text { max. }\end{array}$ & Emp. min. & Emp. max. & AS & SD & $\begin{array}{c}\text { Number } \\
\text { of items }\end{array}$ \\
\hline Interpersonal & 1 & 5 & 4.365 & 4.652 & 4.492 & 2.463 & 6 \\
Socioemotional & 1 & 5 & 3.943 & 4.420 & 4.253 & 2.867 & 6 \\
Pedagogical-psychological & 1 & 5 & 4.247 & 4.436 & 4.376 & 2.841 & 6 \\
Subject-professional & 1 & 5 & 4.125 & 4.475 & 4.299 & 2.865 & 6 \\
Didactic & 1 & 5 & 4.192 & 4.337 & 4.241 & 2.912 & 6 \\
Methodological-statistical-research & 1 & 5 & 4.042 & 4.215 & 4.086 & 3.683 & 6 \\
Multimedia-digital & 1 & 5 & 4.172 & 4.296 & 4.219 & 3.701 & 6 \\
Organizational & 1 & 5 & 4.268 & 4.448 & 4.336 & 2.846 & 6 \\
\hline
\end{tabular}

The results showed that based on the values of arithmetic means that all exceed the values of 4 (Table 4), elementary and secondary school teachers in Southern Serbia, based on their self-assessments, highly value all diverse groups of competencies, which were offered in the assessment scale. Neither of the groups of competencies stands out drastically, but we will mention that the highest values are observed on the subscale of interpersonal (AS = 4.492), and the lowest on the subscale of methodological-statisticalresearch competencies (AS $=4.086$ ), with emphasis on minimal differences. In the framework of further statistical analysis, in order to confirm or refute the set special hypotheses, the existence of statistically significant differences in the degree of expression of attitudes about competency groups with respect to independent research variables was examined.

Table 5.

Differences in the degree of expression of attitudes with regard to the type of school

\begin{tabular}{|c|c|c|c|c|c|c|c|c|}
\hline Variables & $\begin{array}{l}\text { Type of } \\
\text { school }\end{array}$ & $\mathrm{N}$ & AS & SD & t-test & df & $\begin{array}{c}\text { Statistical } \\
\text { significance }\end{array}$ & $\begin{array}{l}\text { Effect } \\
\text { size }\end{array}$ \\
\hline Interpersonal & $\begin{array}{l}\text { Elementary } \\
\text { Secondary }\end{array}$ & $\begin{array}{l}588 \\
712\end{array}$ & $\begin{array}{l}27.178 \\
26.762\end{array}$ & $\begin{array}{l}2.179 \\
2.661\end{array}$ & 3.040 & 1298 & $0.000^{\star \star \star}$ & -0.084 \\
\hline Socioemotional & $\begin{array}{l}\text { Elementary } \\
\text { Secondary }\end{array}$ & $\begin{array}{l}588 \\
712\end{array}$ & $\begin{array}{l}25.481 \\
25.549\end{array}$ & $\begin{array}{l}2.705 \\
2.995\end{array}$ & -0.425 & 1298 & $0.002^{* \star}$ & 0.012 \\
\hline Pedagogical-psychological & $\begin{array}{l}\text { Elementary } \\
\text { Secondary }\end{array}$ & $\begin{array}{l}588 \\
712\end{array}$ & $\begin{array}{l}26.222 \\
26.287\end{array}$ & $\begin{array}{l}2.765 \\
2.904\end{array}$ & -0.411 & 1298 & 0.092 & 0.011 \\
\hline Subject-professional & $\begin{array}{l}\text { Elementary } \\
\text { Secondary }\end{array}$ & $\begin{array}{l}588 \\
712\end{array}$ & $\begin{array}{l}25.722 \\
25.856\end{array}$ & $\begin{array}{l}2.655 \\
2.904\end{array}$ & -0.839 & 1298 & 0.064 & 0.023 \\
\hline Didactic & $\begin{array}{l}\text { Elementary } \\
\text { Secondary }\end{array}$ & $\begin{array}{l}588 \\
712\end{array}$ & $\begin{array}{l}25.387 \\
25.498\end{array}$ & $\begin{array}{l}3.009 \\
2.830\end{array}$ & -0.683 & 1298 & 0.062 & 0.019 \\
\hline $\begin{array}{l}\text { Methodological-statistical- } \\
\text { research }\end{array}$ & $\begin{array}{l}\text { Elementary } \\
\text { Secondary }\end{array}$ & $\begin{array}{l}588 \\
712\end{array}$ & $\begin{array}{l}24.471 \\
24.554\end{array}$ & $\begin{array}{l}3.504 \\
3.827\end{array}$ & -0.408 & 1298 & $0.006^{* *}$ & 0.0011 \\
\hline Multimedia-digital & $\begin{array}{l}\text { Elementary } \\
\text { Secondary }\end{array}$ & $\begin{array}{l}588 \\
712\end{array}$ & $\begin{array}{l}24.947 \\
25.612\end{array}$ & $\begin{array}{l}3.914 \\
3.490\end{array}$ & -3.236 & 1298 & 0.220 & 0.089 \\
\hline Organizational & $\begin{array}{l}\text { Elementary } \\
\text { Secondary }\end{array}$ & $\begin{array}{l}588 \\
712\end{array}$ & $\begin{array}{l}25.726 \\
26.251\end{array}$ & $\begin{array}{l}2.875 \\
2.801\end{array}$ & -3.324 & 1298 & 0.894 & 0.092 \\
\hline
\end{tabular}

Effect size - obtained via Point-biserial correlation coefficient

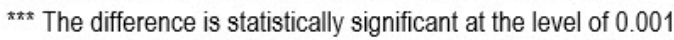

** The difference is statistically significant at the level of 0.01 
To determine the existence of statistically significant differences in the degree of expression of attitudes about competency groups with regard to the type of school, a t-test was performed. The results showed that there are statistically significant differences in terms of the expression of certain dimensions of competencies, namely interpersonal $\left(t_{(1298)}=3,040, p<0.001\right)$, socioemotional $\left(t_{(1298)}=-0,425, p<0.01\right)$, and methodological-statistical-research $\left(\mathrm{t}_{(1298)}=-0.408, \mathrm{p}<0.01\right)$, as evidenced by the data (Table 5). Teachers who work in elementary school have more emphasized interpersonal competences, and teachers who work in secondary school have more emphasized socioemotional and methodological-statistical-research competencies.

Table 6.

Differences in the degree of expression of attitudes with regard to academic achievement (Anova)

\begin{tabular}{|c|c|c|c|c|c|c|c|}
\hline Variables & $\begin{array}{l}\text { Average grade during } \\
\text { completed studies }\end{array}$ & $\mathrm{N}$ & AS & SD & $\mathrm{F}$ & $\mathrm{df}$ & $\begin{array}{c}\text { Statistical } \\
\text { significance }\end{array}$ \\
\hline \multirow{4}{*}{ Interpersonal } & From 6 to 7 & 136 & 27.102 & 1.956 & \multirow{4}{*}{5.595} & \multirow{4}{*}{1299} & \multirow{4}{*}{$0.001^{\star \star}$} \\
\hline & From 7.01 to 8 & 385 & 26.522 & 2.549 & & & \\
\hline & From 8.01 to 9 & 549 & 27.143 & 2.409 & & & \\
\hline & Form 9.01 to 10 & 230 & 27.117 & 2.631 & & & \\
\hline \multirow{4}{*}{ Socioemotional } & From 6 to 7 & 136 & 25.573 & 3.228 & \multirow{4}{*}{9.887} & \multirow{4}{*}{1299} & \multirow{4}{*}{$0.000^{\star \star \star \star *}$} \\
\hline & From 7.01 to 8 & 385 & 24.870 & 2.699 & & & \\
\hline & From 8.01 to 9 & 549 & 25.801 & 2.700 & & & \\
\hline & From 9.01 to 10 & 230 & 25.895 & 3.127 & & & \\
\hline \multirow{4}{*}{$\begin{array}{l}\text { Pedagogical- } \\
\text { psychological }\end{array}$} & From 6 to 7 & 136 & 26.477 & 2.535 & \multirow{4}{*}{4.165} & \multirow{4}{*}{1299} & \multirow{4}{*}{$0.006^{\star \star}$} \\
\hline & From 7.01 to 8 & 385 & 25.831 & 2.885 & & & \\
\hline & From 8.01 to 9 & 549 & 26.428 & 2.894 & & & \\
\hline & From 9.01 to 10 & 230 & 26.439 & 2.747 & & & \\
\hline \multirow{4}{*}{ Subject-professional } & From 6 to 7 & 136 & 25.500 & 3.098 & \multirow{4}{*}{8.443} & \multirow{4}{*}{1299} & \multirow{4}{*}{$0.000^{\star 2 \pi *}$} \\
\hline & From 7.01 to 8 & 385 & 25.254 & 2.991 & & & \\
\hline & From 8.01 to 9 & 549 & 26.107 & 2.667 & & & \\
\hline & From 9.01 to 10 & 230 & 26.134 & 2.824 & & & \\
\hline \multirow{4}{*}{ Didactic } & From 6 to 7 & 136 & 25.250 & 2.445 & \multirow{4}{*}{18.369} & \multirow{4}{*}{1299} & \multirow{4}{*}{$0.000^{\star * \pi}$} \\
\hline & From 7.01 to 8 & 385 & 24.693 & 3.028 & & & \\
\hline & From 8.01 to 9 & 549 & 25.630 & 2.995 & & & \\
\hline & From 9.01 to 10 & 230 & 26.395 & 2.399 & & & \\
\hline \multirow{4}{*}{$\begin{array}{l}\text { Methodological- } \\
\text { statistical-research }\end{array}$} & From 6 to 7 & 136 & 24.477 & 3.936 & \multirow{4}{*}{7.058} & \multirow{4}{*}{1299} & \multirow{4}{*}{$0.000^{\star * \star}$} \\
\hline & From 7.01 to 8 & 385 & 23.820 & 3.576 & & & \\
\hline & From 8.01 to 9 & 549 & 24.887 & 3.715 & & & \\
\hline & From 9.01 to 10 & 230 & 24.821 & 3.479 & & & \\
\hline \multirow{4}{*}{ Multimedia-digital } & From 6 to 7 & 136 & 24.279 & 4.545 & \multirow{4}{*}{12.942} & \multirow{4}{*}{1299} & \multirow{4}{*}{$0.000^{\approx \pi *}$} \\
\hline & From 7.01 to 8 & 385 & 25.075 & 3.462 & & & \\
\hline & From 8.01 to 9 & 549 & 25.218 & 3.963 & & & \\
\hline & From 9.01 to 10 & 230 & 26.539 & 2.361 & & & \\
\hline \multirow{4}{*}{ Organizational } & From 6 to 7 & 136 & 25.529 & 3.001 & & & \\
\hline & From 7.01 to 8 & 385 & 25.735 & 2.933 & & & \\
\hline & From 8.01 to 9 & 549 & 25.950 & 2.970 & 10.589 & 1299 & $0.000^{2 \times x}$ \\
\hline & From 9.01 to 10 & 230 & 26.917 & 1.999 & & & \\
\hline
\end{tabular}

Only in the case of determining the existence of statistically significant differences in the degree of expression of attitudes about the groups of competencies with regard to the academic achievement of teachers, an Analysis of variance was performed. In Table 6 it can be seen that in all eight dimensions of competencies - interpersonal $\left(F_{(1299)}=5.595, p<0.01\right)$, socioemotional $\left(F_{(1299)}=9.887, p<0.001\right)$, pedagogical-psychological $\left(F_{(1299}=4.165, p<0.01\right)$, subject-professional $\left(F_{(1299}=8.443\right.$, $\left.p<0.001\right)$, didactic $\left(F_{(1299)}=18.369, p<0.001\right)$, methodological-statistical-research $\left(F_{(1299)}=7.058, p<0.01\right)$, multimedia-digital $\left(F\left({ }_{1299)}^{1299)}=12.942, p<0.001\right)\right.$, and organizational $\left.\left(F_{(1299)}\right)=10.589, p<0.001\right)$, there are statistically significant differences with regard to the mentioned academic achievement of teachers, ie. their average grade during completed studies. 
Table 7.

Differences in the degree of expression of the competence dimension with regard to academic achievement (Post hoc test)

\begin{tabular}{|c|c|c|c|c|}
\hline Variables & $\begin{array}{l}\text { (I) Average grade } \\
\text { during completed } \\
\text { studies }\end{array}$ & $\begin{array}{l}\text { (J) Average grade } \\
\text { during completed } \\
\text { studies }\end{array}$ & AS Difference $(1-J)$ & $\begin{array}{c}\text { Statistical } \\
\text { significance }\end{array}$ \\
\hline \multirow{3}{*}{ Interpersonal } & \multirow{3}{*}{ From 7.01 to 8} & From 6 to 7 & -0.580 & $0.018^{*}$ \\
\hline & & From 8.01 to 9 & -0.621 & $0.000^{\star \star \star}$ \\
\hline & & From 9.01 to 10 & -0.595 & $0.004^{* *}$ \\
\hline \multirow{3}{*}{ Socioemotional } & \multirow{3}{*}{ From 7.01 to 8} & From 6 to 7 & -0.703 & $0.013^{\star}$ \\
\hline & & From 8.01 to 9 & -0.931 & $0.000^{* * *}$ \\
\hline & & From 9.01 to 10 & -1.025 & $0.000^{* * *}$ \\
\hline \multirow{3}{*}{ Pedagogical-psychological } & \multirow{3}{*}{ From 7.01 to 8} & From 6 to 7 & -0.646 & $0.022^{*}$ \\
\hline & & From 8.01 to 9 & -0.596 & $0.002^{\star *}$ \\
\hline & & Frpm 9.01 to 10 & 0.607 & $0.010^{*}$ \\
\hline \multirow{4}{*}{ Subject-professional } & \multirow{2}{*}{ From 6 to 7} & From 8.01 to 9 & -0.607 & $0.026^{\star}$ \\
\hline & & From 9.01 to 10 & -0.634 & $0.039^{*}$ \\
\hline & \multirow{2}{*}{ From 7.01 to 8} & From 8.01 to 9 & -0.852 & $0.000^{* \star *}$ \\
\hline & & From 9.01 to 10 & -0.880 & $0.000^{\star \star *}$ \\
\hline \multirow{4}{*}{ Didactic } & From 8.01 to 9 & From 7.01 to 8 & 0.936 & $0.000^{\star \star *}$ \\
\hline & \multirow{3}{*}{ From 9.01 to 10} & From 6 to 7 & 1.145 & $0.000^{* \star *}$ \\
\hline & & From 7.01 to 8 & 1.702 & $0.000^{* \star *}$ \\
\hline & & From 8.01 to 9 & 0.765 & $0.001^{* *}$ \\
\hline \multirow{2}{*}{ Methodological-statistical-research } & \multirow{2}{*}{ From 7.01 to 8} & From 8.01 to 9 & -1.066 & $0.000^{\star \star *}$ \\
\hline & & From 9.01 to 10 & -1.000 & $0.001^{* *}$ \\
\hline \multirow{5}{*}{ Multimedia-digital } & \multirow{3}{*}{ From 6 to 7} & From 7.01 to 8 & -0.795 & $0.029^{\star}$ \\
\hline & & From 8.01 to 9 & -.0939 & $0.007^{\star \star}$ \\
\hline & & From 9.01 to 10 & -2.259 & $0.000^{* \star *}$ \\
\hline & \multirow{2}{*}{ From 9.01 to 10} & From 7.01 to 8 & 1.463 & $0.000^{* * *}$ \\
\hline & & From 8.01 to 9 & 1.320 & $0.000^{* * *}$ \\
\hline \multirow{3}{*}{ Organizational } & \multirow{3}{*}{ From 9.01 to 10} & From 6 to 7 & 1.387 & $0.000^{\star \star \star}$ \\
\hline & & From 7.01 to 8 & 1.182 & $0.000^{* \star *}$ \\
\hline & & From 8.01 to 9 & 0.966 & $0,000^{* \star *}$ \\
\hline
\end{tabular}

*** The difference is statistically significant at the level of 0.001

** The difference is statistically significant at the level of 0.01

* The difference is statistically significant at the level of 0.05

In further statistical analysis, in order to determine the differences in the degree of expression of the competence dimension with regard to academic achievement, a Post Hoc test was performed. Teachers whose average grade during their studies was from 7.01 to 8 have less emphasized interpersonal and socioemotional competencies than teachers whose average grades during their studies are below or above this level. Teachers whose average grade during their studies was from 7.01 to 8 have less emphasized pedagogical-psychological competencies than those whose grade was lower and those whose grade was from 8.01 to 9 . However, teachers whose average grade during their studies was from 7.01 to 8 have more emphasized pedagogical-psychological competencies than those whose grade was from 9.01 to 10. Subject-professional, didactic, methodological-statistical-research, multimedia-digital and organizational competencies are more emphasized with teachers who have higher average grades compared to teachers with lower average grades in completed studies (Table 7), which represents the results that we fully expected. 
Table 8.

Differences in the degree of expression of attitudes with regard to attending some of the seminars in the field of educational technologies and the application of multimedia systems in teaching

\begin{tabular}{|c|c|c|c|c|c|c|c|c|}
\hline Variables & $\begin{array}{c}\text { Seminar } \\
\text { attendance }\end{array}$ & $\mathrm{N}$ & AS & SD & t-test & df & $\begin{array}{c}\text { Statistical } \\
\text { significance }\end{array}$ & Effect size \\
\hline Interpersonal & $\begin{array}{l}\text { Yes } \\
\text { No }\end{array}$ & $\begin{array}{l}898 \\
402\end{array}$ & $\begin{array}{l}27.043 \\
26.743\end{array}$ & $\begin{array}{l}2.523 \\
2.311\end{array}$ & 2.030 & 1298 & $0.006^{* *}$ & -0.056 \\
\hline Socioemotional & $\begin{array}{l}\text { Yes } \\
\text { No }\end{array}$ & $\begin{array}{l}898 \\
402\end{array}$ & $\begin{array}{l}25.634 \\
25.258\end{array}$ & $\begin{array}{l}2.691 \\
3.214\end{array}$ & 2.189 & 1298 & $0.000^{* \star *}$ & -0.061 \\
\hline $\begin{array}{l}\text { Pedagogical- } \\
\text { psychological }\end{array}$ & $\begin{array}{l}\text { Yes } \\
\text { No }\end{array}$ & $\begin{array}{l}898 \\
402\end{array}$ & $\begin{array}{l}26.508 \\
25.699\end{array}$ & $\begin{array}{l}2.715 \\
3.033\end{array}$ & 4.790 & 1298 & $0.003^{* *}$ & -0.132 \\
\hline \multirow{2}{*}{$\begin{array}{l}\text { Subject- } \\
\text { professional }\end{array}$} & Yes & 898 & 25.983 & 2.869 & 3.535 & 1298 & 0.616 & -0.098 \\
\hline & No & 402 & 25.378 & 2.814 & & & & \\
\hline \multirow[t]{2}{*}{ Didactic } & Yes & 898 & 25.485 & 2.912 & 0.686 & 1298 & 0.261 & -0.019 \\
\hline & No & 402 & 25.365 & 2.912 & & & & \\
\hline \multirow[t]{2}{*}{$\begin{array}{l}\text { Methodological- } \\
\text { statistical-research }\end{array}$} & Yes & 898 & 24.757 & 3.521 & 3.531 & 1298 & 0.016 & -0.098 \\
\hline & No & 402 & 23.980 & 3.974 & & & & \\
\hline \multirow[t]{2}{*}{ Multimedia-digital } & Yes & 898 & 25.611 & 3.547 & 4.395 & 1298 & $0.002^{* *}$ & -0.121 \\
\hline & No & 402 & 24.641 & 3.948 & & & & \\
\hline \multirow[t]{2}{*}{ Organizational } & Yes & 898 & 26.236 & 2.720 & 4.235 & 1298 & 0.053 & -0.117 \\
\hline & No & 402 & 25.517 & 3.054 & & & & \\
\hline
\end{tabular}

To determine the existence of statistically significant differences in the degree of expression of attitudes about competency groups with regard to attending some of the seminars in the field of educational technologies and the application of multimedia systems in teaching, a t-test was performed. The results (Table 8), indicate the existence of statistically significant differences in terms of the expression of interpersonal $\left(t_{1228)}=2.030, p<0.01\right)$, socioemotional $\left(t_{(1298)}=2.189, p<0.001\right)$, pedagogical-psychological $\left(t_{(1298)}=4.790, p<0.01\right)$, and multimedia-digital competencies $\left(t_{(1298)}=4.395, p<0.05\right)$. Teachers who attended some of the mentioned seminars have more emphasized previously mentioned groups of competencies in relation to teachers who did not attend them. 
Simonović, N. (2021). Teachers' key competencies for innovative teaching, International Journal of Cognitive Research in Science, Engineering and Education (IJCRSEE), 9(3), 331-345.

Table 9.

Differences in the degree of expression of attitudes with regard to the application of internal evaluation

\begin{tabular}{|c|c|c|c|c|c|c|c|c|}
\hline Variables & $\begin{array}{c}\text { Internal } \\
\text { evaluation }\end{array}$ & $\mathrm{N}$ & AS & SD & t-test & df & $\begin{array}{c}\text { Statistical } \\
\text { significance }\end{array}$ & Effect size \\
\hline \multirow{2}{*}{ Interpersonal } & Yes & 740 & 27.070 & 2.319 & \multirow{2}{*}{2.013} & \multirow{2}{*}{1298} & \multirow{2}{*}{$0.001^{\star \star}$} & \multirow{2}{*}{-0.056} \\
\hline & No & 560 & 26.792 & 2.634 & & & & \\
\hline \multirow{2}{*}{ Socioemotional } & Yes & 740 & 25.831 & 2.605 & \multirow{2}{*}{4.553} & \multirow{2}{*}{1298} & \multirow{2}{*}{$0.000^{* \pi *}$} & \multirow{2}{*}{-0.125} \\
\hline & No & 560 & 25.105 & 3.134 & & & & \\
\hline \multirow{2}{*}{$\begin{array}{l}\text { Pedagogical- } \\
\text { psychological }\end{array}$} & Yes & 740 & 26.460 & 2.695 & \multirow{2}{*}{2.960} & \multirow{2}{*}{1298} & \multirow{2}{*}{$0.003^{\star \star}$} & \multirow{2}{*}{-0.082} \\
\hline & No & 560 & 25.991 & 3.005 & & & & \\
\hline \multirow{2}{*}{ Subject-professional } & Yes & 740 & 26.098 & 2.514 & \multirow{2}{*}{4.406} & \multirow{2}{*}{1298} & \multirow{2}{*}{$0.000^{\star \star \pi}$} & \multirow{2}{*}{-0.121} \\
\hline & No & 560 & 25.396 & 3.231 & & & & \\
\hline \multirow{2}{*}{ Didactic } & Yes & 740 & 25.816 & 2.640 & \multirow{2}{*}{5.288} & \multirow{2}{*}{1298} & \multirow{2}{*}{$0.000^{* \pi *}$} & \multirow{2}{*}{-0.145} \\
\hline & No & 560 & 24.962 & 3.174 & & & & \\
\hline \multirow{2}{*}{$\begin{array}{l}\text { Methodological- } \\
\text { statistical-research }\end{array}$} & Yes & 740 & 25.054 & 3.273 & \multirow{2}{*}{6.128} & \multirow{2}{*}{1298} & \multirow{2}{*}{$0.000^{* \pi \star}$} & \multirow{2}{*}{-0.168} \\
\hline & No & 560 & 23.807 & 4.059 & & & & \\
\hline \multirow{2}{*}{ Multimedia-digital } & Yes & 740 & 25.647 & 2.918 & \multirow{2}{*}{3.779} & \multirow{2}{*}{1298} & \multirow{2}{*}{$0.000^{* \pi *}$} & \multirow{2}{*}{-0.104} \\
\hline & No & 560 & 24.867 & 4.498 & & & & \\
\hline \multirow{2}{*}{ Organizational } & Yes & 740 & 26.471 & 2.497 & 6780 & 1298 & $0000 \approx \pi *$ & -0185 \\
\hline & No & 560 & 25.408 & 3.151 & & 1290 & 0.000 & -0.100 \\
\hline
\end{tabular}

Effect size - obtained via Point-biserial correlation coefficient

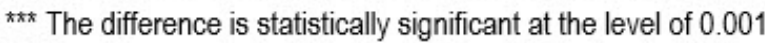

${ }^{* *}$ The difference is statistically significant at the level of 0.01

To determine the existence of statistically significant differences in the degree of expression of attitudes about competence groups with regard to the application of internal evaluation in working with students, a t-test was also performed. The data (Table 9), indicate that there are statistically significant differences in terms of the expression of interpersonal $\left(t_{(1298)}=2.013, p<0.01\right)$, socioemotional $\left(t_{11298}=4.553\right.$, $p<0.001)$, pedagogical-psychological $\left(t_{(1298)}=2.960, p<0.01\right)$, subject-professional $\left(t_{(1298)}=4.406, p<0.001\right)$, didactic $\left(t_{(1298)}=5.288, p<0.001\right)$, methodological-statistical-research $\left(t_{(1298)}=6,128, p<0.001\right)$, multimediadigital $\left(t_{(1298)}=3,779, p<0.001\right)$, and organizational competencies $\left(t_{(1298)}=6,780, p<0.001\right)$. Therefore, we find that all 8 groups of competencies are more emphasized among teachers who apply it in teaching than those who do not apply the specified type of evaluation.

\section{Discussion}

Based on the obtained results after determining the differences in the degree of expression of attitudes about the groups of competencies with regard to sociodemographic characteristics, ie. independent research variables, t-test and Analysis of variance, we came to the following findings: The results of the analysis based on the obtained arithmetic means, which all exceed the values of 4, lead us to the conclusion that teachers, based on their self-assessments, highly valued all various groups of competencies, which fully confirmed the general hypothesis. The results showed that teachers' attitudes about competencies were not concentrated around central values, but they generally considered that certain competencies were to a greater extent or extremely important. We expected this tendency in the evaluation of individual competencies within groups to some extent, because they are all important and necessary for successful engagement in the teaching and educational process. We will also point out that no group of competencies stood out drastically, because the results are relatively uniform and speak of the positive attitudes of teachers towards each of the existing competencies that were the subject of their assessment. However, the highest values were observed on the subscale of interpersonal, and the lowest on the subscale of methodological-statistical-research competencies, with an emphasis on minimal differences. The highest observed values in the interpersonal group of competencies were to some extent expected because this group of competencies, as necessary for establishing, building and improving relationships with students, parents and colleagues, should represent and be the embodiment of universal and fundamental value and the "character of the teacher". The lowest values on the subscale of methodological-statistical-research competencies may also indicate that teachers do not consider this group of competencies less important, but only in relation to other groups of competencies, a slightly lower degree of agreement is shown.

Further statistical analysis that should confirm or refute the presumed special hypotheses, examined the existence of statistically significant differences in the degree of expression of attitudes 
about competency groups with respect to independent research variables.

Based on the results obtained after using the t-test, the first special hypothesis was rejected. We assumed that there were no statistically significant differences in teachers' attitudes about various groups of competencies in relation to the type of school in which they teach (elementary and secondary), as independent variables, because teachers, regardless of the school in which they teach, should highly value all groups of competencies, especially interpersonal, socioemotional, pedagogical-psychological as universal and common to all teachers and participants in the educational process. In this respect, the type of school should not affect the evaluation of a certain group of competencies.

Based on the results obtained after the use of Analysis of variance (Anova), but also the Post Hoc test, which were applied only in this case, the second special hypothesis was partially confirmed. It assumes the existence of statistically significant differences in teachers' attitudes about competency groups in relation to academic achievement, in the sense that teachers who had average grades during completed studies above 8.01, relatively speaking - more successful, value more pedagogicalpsychological and didactic, as well as subject-professional in relation to teachers whose average grades during completed studies are below 8 . The results showed that in addition to methodological-statisticalresearch, multimedia-digital and organizational, teachers with higher average grades emphasized more subject-professional and didactic competencies, as we assumed. Teachers whose average grade during their studies was from 7.01 to 8 emphasized less pedagogical-psychological competencies than teachers with an average grade from 8.01 to 9 , which is in line with our hypothesis, but on the other hand, have emphasized more pedagogical-psychological competencies than teachers with an average score of 9.01 to 10 , on the basis of which this hypothesis could not be fully confirmed but only partially. We did not expect such a result and that cognition brings us to a certain dilemma.

Based on the results obtained after using the t-test, the third special hypothesis was confirmed. It presupposes the existence of statistically significant differences in teachers' attitudes about competency groups in relation to attending some of the seminars in the field of educational technologies and the application of multimedia systems in teaching, in the sense that teachers who attended them value multimedia-digital more than teachers who did not, due to the essential and logical connection of the mentioned phenomena as independent or dependent research variables. The results provided us with the cognition that the teachers who attended some of the mentioned seminars, in addition to the multimediadigital competences, as previously mentioned, emphasized more interpersonal, socioemotional and pedagogical-psychological ones.

The fourth hypothesis in which the assumption is made about the existence of statistically significant differences in teachers' attitudes about competency groups in relation to the application of internal evaluation in working with students, in the sense that teachers who apply it in their work, value subject-professional and didactic in relation to teachers which do not apply it, like the previous one, is fully confirmed. Between the application or non-application of internal evaluation in working with students as independent variables and teachers' attitudes about the evaluation of subject-professional and didactic competencies, a possible direct cause-and-effect relationship and feedback of evaluation results on the quality and effects of teachers' work was noticed. The results, after the use of t-test, which determined the existence of statistically significant differences in terms of expression in all eight groups of competencies, showed and provided us with the knowledge that the teachers who apply it, emphasize more, among all others, and in accordance with our assumption, the subject-professional and didactic group of competencies.

It is important to point out that the results of the research additionally provided us with some very interesting and useful knowledge. Namely, the existence of statistically significant differences in the degree of expression of attitudes about interpersonal, socioemotional and pedagogical-psychological competencies was determined in relation to all 4 independent variables - type of school, academic achievement, attendance of some seminars in the field of educational technologies and multimedia systems, as well as the application of internal evaluation. On the other hand, in relation to independent variables - academic achievement and the application of internal evaluation in teaching, the existence of statistically significant differences is determined in the degree of expression of attitudes in as many as 5 groups of competencies - subject-professional, didactic, methodological-statistical-research, multimediadigital and organizational competencies.

Based on the review of research dealing with similar topics, we especially refer to the results of some previous tangential research on competencies that speak in favor of the importance of all these groups of competencies as key, among other things for innovating the teaching process (Zobenica and Stipančević, 2017; Bogunović and Stanišić, 2013; Andevski and Arsenijević, 2012; Gojkov, 2012). The importance of professional development of teachers for improving the professional competencies of 
teachers in general, and thus raising the quality of the entire teaching process, is indicated in the research by Tapani and Salonen (2019), while Teodorović, Milin and Stanković (2019), compare standards for teacher competencies in Serbia with countries/regions in their research. In the relevant professional literature, we did not encounter research that looked at the existence of statistically significant differences in teachers' attitudes about various groups of competencies in relation to independent variables (type of school, academic achievement, attendance at seminars in the application of educational technologies and multimedia systems in teaching and the application of internal evaluation in teaching), which was the case here. Based on this cognition, there is hope that the research will make a modest contribution to shedding light on similar issues, and the obtained results will represent a good starting point and incentive for further research work in this field in the future.

\section{Conclusion}

The task of every country that wants quality education is that it must inevitably permanently improve the educational policy focused on the field of education and professional development of teachers. Improving the quality of school work is a dynamic process, open to innovations and changes brought about by the accelerated development of modern society. Education as indisputably one of the most dynamic professions requires a certain meta-competence of constant self-examination and finding ways to respond to the always new needs of the future society.

The issue of key competencies of teachers, necessary for innovating the teaching process, is certainly one of the fundamental issues when it comes to good and quality teaching, because innovation changes the pedagogical system, improving the teaching process and its results.

The theoretical significance of this research is reflected in the fact that it is necessary to obtain knowledge and relevant data on the attitudes of teachers shown by self-assessment through the degree of evaluation/non-evaluation of a wide and diverse group of competencies, as well as individual competencies within these groups. The results of the analysis provided us with the cognition that teachers, based on their self-assessments, highly value all various groups of competencies, which fully confirms the general hypothesis. The results also showed the existence of statistically significant differences in the degree of expression of attitudes about competency groups with regard to independent research variables, within special hypotheses, on the basis of which the first was rejected, the second partially, the third and fourth special hypotheses were fully confirmed. We can say with some certainty that the knowledge and results we have obtained are a kind of indicator of the quality of teachers' work and a predictor of their focus on continuous reflection on the effects and effectiveness of their work, application of innovations in teaching, reflectivity and research to improve their own work, but also the entire educational work. Also, the cognition of the existence of statistically significant differences in teachers' attitudes about key competencies for innovation in relation to independent variables (type of school where the teacher teaches, academic achievement of teachers, attending seminars in the field of educational technologies and multimedia systems in teaching, and finally internal evaluation in teaching), would significantly contribute to the consolidation or refutation of the attitude on the connection of these phenomena and thus indicate a realistic picture of the set goal.

In addition to the theoretical, the research certainly has practical significance and more far-reaching implications, which are reflected in the fact that it is desirable to find out what the attitudes of teachers on this issue are, as direct participants in the teaching process. All this is crucial and invaluable because it enables teachers to always keep pace with social progress, therefore it is necessary to raise awareness and point out the importance of research work, focus on reflection, application of innovations in teaching and possession of developed various competency groups which is generally the topic of this research. Only in this way do teachers trace the path to teaching in which research, innovation, critical reflection and only with such an approach will they be directed towards reflective practice and declare themselves as reflective practitioners. The implications of research can also potentially be important for creators of educational strategies that define the domains of teachers' professional competencies, because despite their enviable theoretical foundation, there is always room for further empirical research in perspective.

Teacher competencies are the capacity of an individual that is realized through performing complex activities during educational work and include a set of certain knowledge, skills and attitudes of teachers with which he influences the improvement of the entire educational process. Given that the educational process is by its nature and essence very dialectical, teachers are faced with quite justified requirements to have developed a whole mix of diverse groups and individual competencies within these groups, in order to always be at a high level in their work and fulfill their roles in a flexible way. 
Today's school, in accordance with modern tendencies, indisputably needs a "new profile" of a modern teacher, with a wide range of developed competencies, which would enable them to successfully organize work, motivate and encourage students, critically reflect on their practice, independently research and use these results for the purpose of self-improvement. The positive attitudes of teachers about the important role and exceptional importance of having a wide range of individual competencies for teaching innovations, shown through the high evaluation of all offered groups of competencies, are certainly encouraging. Based on the previous postulates, we can conclude that all these groups of competencies are important and crucial for innovating the teaching process and that they represent the necessity of the modern age for all employees in education and not just an ideal.

\section{Acknowledgements}

The author would like to express his gratitude to all the participants of the research (elementary and secondary school teachers on the territory of Southern Serbia). The author is especially grateful to Full professor Dr. Jelena Maksimović and assistant Dr. Jelena Osmanović Zajić, both from the Department of Pedagogy, Faculty of Philosophy at the University of Niš, for their support in writing this paper.

\section{Conflict of interests}

The author declares no conflict of interest.

\section{References}

Adelabu, O. A. \& Adu, E. O. (2015). An Investigation into Teacher's Competence on Information Communication and Technologies (ICT) and Availability of E-Learning Resources in the Teaching of Mathematics in Secondary Schools. In S. Carliner, C. Fulford \& N. Ostashewski (Eds.), Proceedings of EdMedia 2015--World Conference on Educational Media and Technology (pp. 882-889). Montreal, Quebec, Canada: Association for the Advancement of Computing in Education (AACE). Retrieved from https://www.learntechlib.org/primary/p/151359/

Albareda-Tiana, S., Vidal-Raméntol, S., Pujol-Valls, M., \& Fernández-Morilla, M. (2018). Holistic approaches to develop sustainability and research competencies in pre-service teacher training. Sustainability, 10(10), 3698. https://doi. org/10.3390/su10103698

Andevski, M., \& Arsenijević, J. (2012). Kompetencije zaposlenih u obrazovanju. [Competencies of employees in education]. Istraživanja u pedagogiji, 2(1), 29-50. Retrieved from http://www.sao.org.rs/documents/2012/lstrazivanja\%20u\%20 pedagogiij\%202.pdf

Anugerahwati, M., \& Saukah, A. (2010). Professional competence of English teachers in Indonesia: A profile of exemplary teachers. Indonesian JELT: Indonesian Journal of English Language Teaching 6(2), 47-59. Retrieved from http://ojs. atmajaya.ac.id/index.php/ijelt/article/view/170

Baumert, J., \& Kunter, M. (2013). The COACTIV model of teachers' professional competence. In M. Kunter, J. Baumert, W. Blum, U. Klusmann, S. Krauss, \& S. M. Neubrand (Ed.), Cognitive Activation in the Mathematics Classroom and Professional Competence of Teachers. Results from the COACTIV Project. Teacher Education, 8 (pp. 28-48). Boston; London: Springer. https://doi.org/10.1007/978-1-4614-5149-5_2

Bertschy, F., Künzli, C., \& Lehmann., M. (2013). Teachers' Competencies for the Implementation of Educational Offers in the Field of Education for Sustainable Development. Sustainability, 5, 5067-5080. https://doi.org/10.3390/su5125067

Bogunović, B., \& Stanišić, J. (2013). Kompetencije nastavnika muzičkih i opšteobrazovnih škola [Competencies of teachers of music and general education schools]. Pedagogija, 67(2), 193-206. Retrieved from https://www.researchgate.net/ profile/Blanka_Bogunovic/publication/313744793_Kompetencije_nastavnika_u_muzickih_i_opsteobrazovnih_skola/ links/58a47dc892851cf0e387287e/Kompetencije-nastavnika-u-muzickih-i-opsteobrazovnih-skola.pdf

Branekova, D. (2010). Information-communicative competence in teachers qualification. Trakia Journal of Sciences, 8(3), 369372. Retrieved from http://tru.uni-sz.bg/tsj/Vol8.Suppl.3.2010/D.Brunekova.pdf

Brundiers, K., \& Wiek, A. (2017). Beyond Interpersonal Competence: Teaching and Learning Professional Skills in Sustainability. Education Sciences, 7(39), 1-18. https://doi.org/10.3390/educsci7010039

Brust Nemet, M., \& Velki, T. (2016). The Social, Emotional and Educational Competences of Teachers as Predictors of Various Aspects of the School Culture. Croatian Journal of Education, 18(4), 1087-1119. https://doi.org/10.15516/cje.v18i4.2006

Buljubašić-Kuzmanović, V. (2014). Integrirani kurikulum u funkciji razvoja pedagoških kompetencija [Integrated curriculum in the function of development of pedagogical competencies]. Pedagogijska istraživanja, 11(1), 95-109. Retrieved from https://scholar.google.com/scholar?hl=en\&as_sdt=0\%2C5\&q=Buljuba\%C5\%A1i\%C4\%87-Kuzmanovi $\%$ C4\%87\%2C+ V.+\%282014\%29.+Integrirani+kurikulum+u+funkciji+razvoja+pedago\%C5\%A1kih\%09kompetencija.\%09Pedagogojs ka+istra\%C5\%BEivanja $\% 2 C+11+\% 281 \% 29 \% 2 C+95-109 .+\& b t n G=$

Cabero-Almenara, J., Gutiérrez-Castillo, J., Palacios-Rodríguez, A., \& Barroso-Osuna, J. (2020). Development of the Teacher Digital Competence Validation of DigCompEdu Check-In Questionnaire in the University Context of Andalusia (Spain). Sustainability, 12(6094), 1-14. https://doi.org/10.3390/su12156094

Call, K. (2018). Professional Teaching Standards: A Comparative Analysis of Their History, Implementation and Efficacy. Australian Journal of Teacher Education, 43(3). http://dx.doi.org/10.14221/ajte.2018v43n3.6

Chai, C. S., Koh, J. H. L., \& Tsai, C. C. (2013). A Review of Technological Pedagogical Content Knowledge. Educational Technology and Society, 16(2), 31-51. Retrieved from https://www.jstor.org/stable/pdf/jeductechsoci.16.2.31.pdf?seq=1 
Simonović, N. (2021). Teachers' key competencies for innovative teaching, International Journal of Cognitive Research in Science, Engineering and Education (IJCRSEE), 9(3), 331-345.

Chen, F., Gorbunova, N. V., \& Masalimova, A. R. (2017). Formation of ICT - Competence of future University school teachers. EURASIA - Journal of Mathematics Science and Technology Education, 13(8), 4765-4777. https://doi.org/10.12973/ eurasia.2017.00963a

Chiriac, E. H., \& Granström, K. (2012). Teachers' leadership and students' experience of group work. Teachers and Teaching - Theory and Practice, 18(3), 345-363. https://doi.org/10.1080/13540602.2012.629842

Cortes, J., \& Lau, J. (2009). Information Skills: Conceptual Convergence between Information and Communication Sciences. Comunicar Journal: Mapping media education policies in the world: visions, programmes, challanges, 32(16), 25-39. https://doi.org/10.3916/c32-2009-02-001

Dorman, E. (2015). Building teachers' social-emotional competence through mindfulness practices. Curriculum and Teaching Dialogue, 17(1-2), 103-119. Retrieved from https://www.fortlewis.edu/Portals/2/TeacherSocialEmotionalCompetence. pdf

Dubovicki, S., \& Jukić, R. (2017). The importance of acquiring pedagogical and didactic competencies of future teachers - the Croatian context. Journal Early Child Development and Care, 187(10), 1557-1568. https://doi.org/10.1080/03004430 .2017.1307839

Duh, M., Bratina, T., \& Krašna, M. (2013). Kompetencije učitelja u osnovnim školama za pripremu materijala za multimedijsko učenje [Competencies of teachers in primary schools for the preparation of materials for multimedia learning]. Informatol, 46, 333-342. Retrieved from https://hrcak.srce.hr/index.php?id_clanak_jezik=167067\&show=clanak

Đuranović, M., Klasnić, I., \& Lapat, G. (2013). Pedagoške kompetencije učitelja u primarnom obrazovanju [Pedagogical competencies of teachers in primary education]. Život i škola: Časopis za teoriju i praksu odgoja i obrazovanja, 59(29), 34-44. Retrieved from https://hrcak.srce.hr/index.php?show=clanak\&id_clanak_jezik=179382

Englefield, E., Black, S. A., Copsey, J. A., \& Knight, A. T. (2019). Interpersonal competencies define effective conservation leadership. Biological Conservation, 235, 18-26. https://doi.org/10.1016/j.biocon.2019.03.043

Fairman, J. C., \& Mackenzie, S. V. (2012). Spheres of teacher leadership action for learning. Journal of Professional Development in Education, 38(2), 229-246. https://doi.org/10.1080/19415257.2012.657865

Falloon, G. (2020). From digital literacy to digital competence: the teacher digital competency (TDC) framework. Education Technology Research Development, 68, 2449-2472. https://doi.org/10.1007/s11423-020-09767-4

Feng, C. S., Gorbunova, N. V., Masalimova, A. R., \& Bírová, J. (2017). Formation of ICT Competence of Future University School Teachers. EURASIA Journal of Mathematics Science and Technology Education, 13(8), 4765-4777. https://doi. org/10.12973/eurasia.2017.00963a

Ferrari, A. (2012). Digital Competence in Practice: An Analysis of Frameworks. Institute for Prospective Technological Studies, European Commission Joint Research Centre. Retrieved from https://pdfs.semanticscholar.org/851f/ ebe72df176a16ad6e26b00ff5df35520da34.pdf

Fiorilli, C., Albanese, O., Gabola, P., \& Pepe, A. (2017). Teachers' Emotional Competence and Social Support: Assessing the Mediating Role of Teacher Burnout. Scandinavian Journal of Educational Research, 61(2), 127-138. https://doi.org/10 $.1080 / 00313831.2015 .1119722$

Gojkov, G., \& Stojanović, A. (2015). Didaktičke kompetencije i evropski kvalifikacioni okvir [Didactic competencies and European qualifications framework]. Beograd: Srpska akademija obrazovanja. Retrieved from http://www.sao.org.rs/ documents/2016/Didakticke\%20kompetencije\%20Gojkov\%20-\%20Stojanovic.pdf

Gojkov, G. (2012). Pedagoška praksa i razvoj kompetencija budućih učitelja [Pedagogical practice and development of competencies of future teachers]. U M. Zuljan-Valenčić, G. Gojkov, A. Rončević, i J. Vogrinc (Ur.), Pedagoška praksa i proces razvijanja kompetencija studenata budućih učitelja u Hrvatskoj, Srbiji i Sloveniji (str. 3-50). Vršac: Visoka vaspitačka škola „Mihailo Palov”.

Guseva, T. K. (2013). Modern primary school and professional competence of teachers. American Journal of Pedagogy and Education, 2, 9-12. Retrieved from http://sbook.us/ajpe/archives/AJPE-2013-2.pdf\#page=9

Instefjord, E. J., \& Munthe, E. (2017). Educating digitally competent teachers: A study of integration of professional digital competence in teacher education. Teaching and Teacher Education, 67, 37-45. https://doi.org/10.1016/j. tate.2017.05.016

Jorgić, D. (2015). Razvoj profesionalnih kompetencija nastavnika [Development of professional competencies of teachers]. Banja Luka: Filozofski fakultet. Retrieved from http://drazenkojorgic.com/wp-content/uploads/2015/09/Razvojprofesionalnih-kompetencija-nastavnika.pdf

Jurčić, M. (2014). Kompetentnost nastavnika - pedagoške i didaktičke dimenzije [Teacher competence - pedagogical and didactic dimensions]. Pedagogijska istraživanja, 11(1), 77-93. Retrieved from https://pdfs.semanticscholar.org/bcb2/ a79698c5cbd27239abd28b9e35c9daa04a28.pdf

Koichu, B., \& Pinto, A. (2018). Developing Education Research Competencies in Mathematics Teachers Through TRAIL: Teacher-Researcher Alliance for Investigating Learning. Canadian Journal of Science, Mathematics and Technology Education, 18, 68-85. https://doi.org/10.1007/s42330-018-0006-3

Kožuh, A., Maksimović, J., \& Osmanović Zajić, J. (2021). Fourth Industrial Revolution and digital competences of teachers. World Journal on Educational Technology: Current Issues, 13(2), 160-177. https://doi.org/10.18844/wjet.v13i2.5651

Kuhnigk, O., Schreiner, J., \& Harendza, S. (2013). Sustained change in didactic skills - does teacher training last? GMS Zeitschrift für Medizinische Ausbildung, 30(3), 1-21. https://dx.doi.org/10.3205\%2Fzma000880

Kunter, M., Klusmann, U., Baumert, J., Richter, D., Voss, T., \& Hachfeld, A. (2013). Professional competence of teachers: Effects on instructional quality and student development. Journal of Educational Psychology, 105(3), 805-820. https:// psycnet.apa.org/doi/10.1037/a0032583

Letina, A. (2016). Effectiveness of Inquiry-Based Science and Social Studies Teaching in the Development of Students' Scientific Competence. Croatian Journal of Education, 18(3), 665-696. https://doi.org/10.15516/cje.v18i3.1735

Liakopoulou, M. (2011). Teachers' Pedagogical Competence as a Prerequisite for Entering the Profession. European Journal of Education - Research, Development and Policy, 46(4), 474-488. https://doi.org/10.1111/j.1465-3435.2011.01495.x

Livazović, G. (2012). Pedagoško utemeljenje kurikuluma socijalnih kompetencija u školi [Pedagogical foundation of the curriculum of social competencies in school]. Pedagogijska istraživanja, 9(1-2), 59-81. Retrieved from https://core. ac.uk/download/pdf/19443682.pdf 
Simonović, N. (2021). Teachers' key competencies for innovative teaching, International Journal of Cognitive Research in Science, Engineering and Education (IJCRSEE), 9(3), 331-345.

Maksimović, J., Osmanović, J., \& Mamutović, A. (2020). Kompetencije nastavnika za medijsko obrazovanje [Teacher competencies for media education]. In Medias Res - Časopis filozofije medija, 9(17), 2685-2707. https://doi. org/10.46640/imr.9.17.7

Malaspina, U., Mallart, A., \& Font, V. (2015). Development of teachers' mathematical and didactic competencies by means of problem posing. CERME 9 - Ninth Congress of the European Society for Research in Mathematics Education, Charles University in Prague, Faculty of Education, 2861-2866. Retrieved from https://hal.archives-ouvertes.fr/hal-01289630/ document

Matijević, M., \& Topolovčan, T. (2017). Izazovi i trendovi u multimedijskoj didaktici [Challenges and trends in multimedia didactics]. Radovi Zavoda za znanstvenoistraživački i umjetnički rad u Bjelovaru, 11(11), 87-99. http://doi.org/10.21857/ mjrl3uxqz9

Miljković, Lj., \& Trnavac, D. (2020). Razvoj kompetencija za demokratsko društvo u digitalnom dobu [Development of competencies for a democratic society in the digital age]. Baština, 51, 299-313. https://doi.org/10.5937/bastina30-27135

Milošević, Z., \& Medić, S. (2018). Programi za razvoj didaktičkih kompetencija univerzitetskih nastavnika i ciljevi nastave visokoškolskog obrazovanja [Programs for the development of didactic competencies of university teachers and goals of higher education teaching]. Obrazovanje odraslih - Casopis za obrazovanje odraslih i kulturu, 18(1), 11-30. Retrieved from https://epale.ec.europa.eu/sites/default/files/journal for adult education july 2018.pdf

Mirete, A. B., Maquilón, J. J., Mirete, L., \& Rodríguez, R. A. (2020). Digital Competence and University Teachers' Conceptions about Teaching 'A Structural Causal Model. Sustainability, 12(4842), 1-13. https://doi.org/10.3390/su12124842

Müller, M., \& Varga, M. A. (2020). Digital competencies of teachers and associates at higher educational institutions in the Republic of Croatia. Informatol, 53(1-2), 8-23. https://doi.org/10.32914/i.53.1-2.2

Nessipbayeva, O. (2012). The competencies of the modern teacher. Bulgarian Comparative Education Society, 148-154. Paper presented at the Annual Meeting of the Bulgarian Comparative Education Society $\left(10^{\text {th }}\right.$, Kyustendil, Bulgaria, Jun 12-15, 2012). Retrieved from https://pdfs.semanticscholar.org/f75f/e8faa5cf0f0ea3ce6355887ae62d21895ec7. pdf? ga $=2.84235164 .485893015 .1597426405-1620032504.1596146691$

Nikitchenko, L. (2017). Forming Professional Competence in The Process of Teaching Biology Students. Наука і освіma, 8, 78-82. https://doi.org/10.24195/2414-4665-2017-8-11

Nikolić, B. (2015). Razmenom profesionalnih iskustava učitelja do inovativnosti u obrazovanju [By exchanging professional experiences of teachers to innovation in education]. Zbornik radova Učiteljskog fakulteta, 9, 315-319. https://doi. org/10.5937/zrufpl1509315N

Novković Cvetković, B., Stošić, L., \& Belousova, A. (2018). Media and Information Literacy - the Basis for Applying Digital Technologies in Teaching from the Discourse of Educational Needs of Teachers. Croatian Journal of Education, 20(4), 1089-1114. https://doi.org/10.15516/cje.v20i4.3001

Panić, N., \& Wubbels, T. (2010). Teacher competencies as a basis for teacher education Views of Serbian teachers and teacher educators. Teaching and Teacher Education, 26, 694-703. https://doi.org/10.1016/j.tate.2009.10.005

Ricardo-Barreto, C., Jabba Molinares, D., Llinás, H., Peña Santodomingo, J., Astorga Acevedo, C., Acevedo Rodríguez, P., Baloco Navarro, C., \& Villarreal Villa, S. (2020). Trends in using ICT resources by professors in HEls (Higher Education Institutions). Journal of Information Technology Education: Research, 19, 395-425. https://doi.org/10.28945/4601

Ristić, M. (2018). Digitalne kompetencije nastavnika i saradnika [Digital competencies of teachers and associates]. XXIV Skup Trendovi Razvoja: ,Digitalizacija viskokog obrazovanja”, Kopaonik, 1-4. Retrieved from http://www.trend.uns.ac.rs/ stskup/trend_2018/radovi/T1-4/T1.4-6.pdf

Schellenbach-Zell, J., \& Gräsel, C. (2010). Teacher motivation for participating in school innovations supporting factors. Journal for Educational Research Online, 2(2), 34-54. Retrieved from https://www.pedocs.de/volltexte/2011/4574/pdf/ JERO_2010_2_Schellenbach_Graesel_Teacher_motivation_for_participating_S34_D_A.pdf

Selvi, K. (2010). Teachers' Competencies. International Journal of Philosophy of Culture and Axiology, 7(1), 167-175. https:// doi.org/10.5840/cultura20107133

Sigrid-Blömeke, S. (2017). Modelling teachers' professional competence as a multi-dimensional construct. Educational Research and Innovation, 119-135. https://doi.org/10.1787/9789264270695-7-en

Stanković, Z., \& Stanojević, D. (2019). Didaktičke inovacije u teoriji i nastavnoj praksi [Didactic innovations in theory and teaching practice]. Niš: Filozofski fakultet.

Stanković, Z., Maksimović, J., \& Osmanović, J. (2018). Cognitive theories and paradigmatic research posts in the function of multimedia teaching and learning. International Journal of Cognitive Research in Science, Engineering and Education (IJCRSEE), 6(2), 107-114. https://doi.org/10.5937/ijcrsee1802107S

Stošić, L., Dermendzhieva S., \& Tomczyk, L. (2020). Information and communication technologies as a source of education. World Journal on Educational Technology: Current Issues, 12(2), 128-135. https://doi.org/10.18844/wjet.v12i2.4815

Tapani, A., \& Salonen, A. O. (2019). Identifying teachers' competencies in Finnish vocational education. International Journal for Research in Vocational Education and Training (IJRVET), 6(3), 243-260. https://doi.org/10.13152/IJRVET.6.3.3

Taylor, L. A. (2017). How teachers become teacher researchers: Narrative as a tool for teacher identity construction. Teaching and Teacher Education, 61, 16-25. https://doi.org/10.1016/j.tate.2016.09.008

Tejedor, G., Segalàs, J., Barrón, A., Fernández-Morilla, M., Fuertes, M. T., Ruiz-Morales, J., Gutiérrez, I., García-González, E., Aramburuzabala, P., \& Hernández, A. (2019). Didactic Strategies to Promote Competencies in Sustainability. Sustainability, 11, 1-24. https://doi.org/10.3390/su11072086

Teodorović, J., Milin, V., \& Stanković, D. (2019). Standardi kompetencija za nastavnike u Srbiji: Poređenje sa odabranim zemljama [Competence standards for teachers in Serbia: Comparison with selected countries]. Zbornik Instituta za pedagoška istraživanja, 51(2), 614-653. https://doi.org/10.2298/ZIPI1902614T

Tichá, M., \& Hošpesová, A. (2013). Developing teachers' subject didactic competence through problem posing. International Journal of Science and Educational Studies in Mathematics, 83, 133-143. https://doi.org/10.1007/s10649-012-9455-1

Turk, M. (2016). (Nove) kompetencije akademske profesije u Europi [(New) competencies of the academic profession in Europe]. Napredak, 157(1-2), 145-164. Retrieved from https://hrcak.srce.hr/177228

Voss, T., \& Kunter, M. (2013). Teachers' General Pedagogical/Psychological Knowledge. In M. Kunter, J. Baumert, W. Blum, U. Klusmann, S. Krauss, \& M. Neubrand (Ed.), Cognitive Activation in the Mathematics Classroom and Professional 
Competence of Teachers. Mathematics Teacher Education, 8 (pp. 207-227). New York: Springer. https://doi. org/10.1007/978-1-4614-5149-5_10

Vrkić-Dimić, J. (2013). Kompetencije učenika i nastavnika za 21. Stoljeće [Competences of students and teachers for the $21^{\text {st }}$ Century]. Acta ladertina, 10, 49-60. Retrieved from https://hrcak.srce.hr/190113

Wambiri, G., \& Ndani, M. N. (2016). Kenya University school teachers' Preparation in ICT Teaching: Teacher Beliefs, Attitudes, Self-Efficacy, Computer Competence, and Age. African Journal of Teacher Education, 5, 49-55. https://doi. org/10.21083/ajote.v5i1.3515

Wareerat, K., Rujroad, K., Skonchai, C., Wanintorn, S., \& Sureeporn, S. (2016). The Development of the Teachers' Researcher Network to Create Instructional Innovation for Raising Students' Learning Achievement in Science and Mathematics, Thailand. Advanced Science Letters, 22(12), 4514-4518. https://doi.org/10.1166/asl.2016.8206

Witfelt, C. (2000). Educational Multimedia and Teacher's Needs For New Competencies: A Study Of Compulsory School Teacher's Need For Competence To Use Educational Multimedia. EMI (Education Media International) - Euro Education, 37(4), 235-241. https://doi.org/10.1080/09523980050210420

Xu, Y., \& Patmor, G. (2012). Fostering Leadership Skills in Pre-Service Teachers. International Journal of Teaching and Learning in Higher Education, 24(2), 252-256. Retrieved from https://files.eric.ed.gov/fulltext/EJ996270.pdf

Zobenica, N., \& Stipančević, A. (2017). Uloga i kompetencije nastavnika u globalizovanom društvu [The role and competencies of teachers in a globalized society]. Pedagoška stvarnost, 63(2), 107-119. https://doi.org/10.19090/ps.2017.2.107-119 